\title{
Implementasi Metode Pewarnaan Graf Menggunakan Algoritma Welch Powell untuk Simulasi Penerapan Frekuensi Radio di Jawa Timur
}

\author{
Fadhlan Septianto Eka Putra, Darmaji, dan Soetrisno \\ Departemen Matematika, Fakultas Matematka dan Ilmu Pengetahuan Alam, Institut Teknologi \\ Sepuluh Nopember (ITS) \\ e-mail: soetrisno@matematika.its.ac.id
}

\begin{abstract}
Abstrak - Interferensi frekuensi radio merupakan permasalahan umum yang di hadapi oleh instansi pemerintah dalam pengelolaan frekuensi radio FM. Interferensi menjadi kelemahan dalam pengelolaan frekuensi radio FM dimana permasalahan yang terjadi adalah adanya 'tubrukan' pada dua stasiun radio dengan frekuensi yang sama. Interferensi memberikan dampak negatif yang signifikan terhadap kinerja jaringan nirkabel. Akibatnya penerimaan suara pada stasiun radio FM di Jawa Timur yang mengalami interferensi menghasilkan kualitas suara yang buruk. Pada penelitian ini, dilakukan penggunaan algoritma welch powell dalam menyelesaikan masalah interferensi dan mengoptimalkan pengalokasian frekuensi radio FM. Hasil dari penelitian ini menunjukan Algoritma Welch Powell dapat menyelesaikan masalah interferensi dan mengoptimalkan pengalokasian frekuensi di Jawa Timur tanpa adanya frekuensi yang bertubrukan, dengan menggunakan data real stasiun radio FM yang ada di Jawa Timur, Algoritma Welch Powell menghasilkan pengalokasian frekuensi yang lebih optimal. Karena jumlah frekuensi yang dihasilkan dengan algoritma Welch Powell lebih minimum dibandingkan jumlah frekuensi yang digunakan data real.
\end{abstract}

Kata Kunci-Interferensi, Noise, Pewarnaan Graf, Algoritma Welch Powell.

\section{PENDAHULUAN}

$\mathrm{R}$ ADIO adalah salah satu media informasi yang masih digunakan sampai saat ini. Di provinsi jawa timur terdapat stasiun berjumlah 115 radio FM [1]. Terdapat radio yang mempunyai frekuensi sama namun berbeda kota, yaitu radio RRI Surabaya dan radio Purnama Cipta Prawira di Blitar. Kedua radio tersebut mempunyai frekuensi yang sama yaitu pada frekuensi 95.30 dan kedua radio tersebut berjarak $100 \mathrm{Km}$. Hal tersebut dapat mengakibatkan interferensi pada radius yang bertubrukan. Jangkauan frekuensi radio FM tidak sejauh frekuensi radio AM. Jangkauan frekuensi radio AM mencapai $120 \mathrm{Km}$ dikarenakan bantuan oleh lapisan ionosfer (berada diantara $80 \mathrm{Km}$ sampai $100 \mathrm{Km}$ dari permukaan bumi). Namun frekuensi radio FM dapat mencapai jarak maksimum Coverage Area $60 \mathrm{Km}$ sampai $70 \mathrm{Km} \mathrm{[2].}$ Terdapat gelombang frekuensi FM yang dihantarkan melalui lapisan troposfer, sehingga siaran FM bisa diterima sampai jarak yang jauh [3]. Dengan jarak Coverage Area yang mencapai $60 \mathrm{Km}$. Terdapat kemungkinan terjadinya interferensi pada daerah tertentu. Interferensi adalah sebuah emisi koheren yang memiliki konten spektral relatif sempit, misalnya radio emisi dari pemancar lain di sekitar frekuensi yang sama dan menghambat penerimaan sinyal. Definisi dari spektral relatif sempit adalah terbatasnya panjang spektrum frekuensi pada frekuensi FM.

Spektrum frekuensi radio adalah susunan pita frekuensi radio yang mempunyai frekuensi lebih kecil dari $3000 \mathrm{GHz}$. Spektrum frekuensi radio merambat dan terdapat dalam dirgantara (ruang udara dan antariksa). Spektrum frekuensi radio merupakan sumber daya alam terbatas, namun saat ini peminatnya semakin meningkat sementara jumlah ketersediaan spektrum tidak bertambah. Spektrum frekuensi radio digunakan untuk pemancar frekuensi radio. Dalam hal penggunaan spektrum frekuensi radio perlu dilakukan koordinasi antar kota. Interferensi memberikan dampak negatif yang signifikan terhadap kinerja jaringan nirkabel. Dalam hal ini penulis menganalisis masalah interferensi dari sudut pandang teori graf dengan menggunakan metode pewarnaan graf.

Optimalisasi frekuensi radio adalah mengoptimalkan pengalokasian frekuensi radio FM sehingga pengguna pemancar frekuensi sebanyak-banyaknya, dengan jumlah pemakaian alokasi frekuensi sesedikit mungkin. Optimalisasi frekuensi radio bertujuan menghindari interferensi frekuensi radio. Permasalahan interferensi radio di jawa timur adalah terdapat stasiun radio FM yang mempunyai frekuensi yang sama dan menyebabkan terjadinya tubrukan radius pancaran frekuensi radio di daerah tersebut. Dampak dari interferensi tersebut yaitu dapat mengakibatkan noise pada frekuensi radio. Noise adalah sinyal-sinyal yang tidak diinginkan yang selalu ada dalam suatu sistem transmisi. Noise mengakibatkan gangguan kualitas sinyal untuk proses penerimaan dan pengiriman suara [3]. Metode pewarnaan graf dapat diimplementasikan ke dalam permasalahan interferensi frekuensi radio di jawa timur. Dengan mensimulasikan pengguna radio yang relatif terhadap posisi stasiun radio diasumsikan sebagai node dan interferensi yang terjadi diasumsikan menjadi lintasan. Pada penelitian ini penulis menggunakan algoritma welch powell untuk optimalisasi frekuensi radio agar tidak ada frekuensi sama yang mengalami interferensi. Algoritma welch powell adalah teknik pewarnaan simpul, dimana simpul yang bertetangga akan memiliki warna yang berbeda. Warna di sini adalah gambaran dari ferkuensi yang dimiliki suatu pemancar. 
Pewarnaan graf adalah pemberian warna terhadap simpul sedemikian sehingga dua simpul yang berdampingan mempunyai warna yang berlainan. Jumlah minimum warna yang dibutuhkan disebut bilangan khromatik dari graf $\mathrm{G}$, dimana khromatik dari graf $\mathrm{G}$ adalah jumlah warna minimum yang diperlukan untuk mewarnai graf $\mathrm{G}$, dan dilambangkan dengan $\chi(\mathrm{G})$. Dengan menggunakan metode pewarnaan graf yang dapat diterapkan dalam permasalahan interferensi sinyal radio, akan menghindari interferensi yang terjadi di spektrum frekuensi radio. FM

Permasalahan interferensi tidak hanya terjadi pada jaringan nirkabel seperti telepon seluler, namun juga terjadi pada jaringan nirkabel siaran radio. Maaly A. Hassan dan Andrew Chickadel pada tahun 2011 melakukan penelitian yang berjudul A Review of Interference Reduction in Wireless Networks Using Graph Coloring Methods. Pada penelitian tersebut dibahas mengenai Interferensi yang terjadi pada jaringan nirkabel. Penggunaan beberapa metode seperti metode weighted coloring, metode dynamic channel assignment, metode location-oblivious untuk menyelesaian permasalahan interferensi. Dalam pembahasan penelitian tersebut dijelaskan bahwa metode dynamic channel assignment adalah metode yang optimal dalam pembahasan penelitian tersebut. Selanjutnya, pada tahun 2010, telah dilakukan penelitian oleh Margaretha Siahaan yang berjudul Studi Pewarnaan Graf pada Radio Frequency Assignment Problem. Pada penelitian ini dibahas mengenai sebuah model frequency assignment problem untuk mengoptimalisasi bidang frekuensi dengan menggunakan pewarnaan simpul dan teknik kromatik polynomial dengan mencari jumlah warna paling sedikit untuk pewarnaan graf. Frequency Assignment Problem pada dasarnya merupakan cara untuk mencari jarak terkecil antara dua buah pemancar agar pemancar tersebut tidak saling berinterferensi dan dapat memancarkan gelombang melalui saluran-saluran yang tersedia. Frequency assignment problem pertama kali muncul di tahun 1960. Perkembangan dari layanan nirkabel seperti telepon selular pertama memulai proses kelangkaan frekuensi dalam spectrum radio. Frequency Assignment Problem yang juga dikenal sebagai channel assignment problem, berkembang dengan cukup cepat. Teknik pewarnaan graf dapat diimplementasikan untuk menemukan nomor warna yang paling kecil yang menghubungkan kedua pemancar yang direpresentasikan sebagai node.

Berdasarkan penelitian diatas, penerapan pewarnaan graf sudah banyak digunakan dalam kehidupan sehari-hari. Oleh karena itu, pada Tugas Akhir ini akan digunakan pewarnaan graf menggunakan Algoritma Welch Powell untuk simulasi interferensi frekuensi radio di Jawa Timur. Sehingga dapat meminimalisasikan interferensi frekuensi radio di Jawa Timur.

\section{TINJAUAN PUSTAKA}

\section{A. Pewarnaan Graf}

Pewarnaan graf merupakan pemberian warna pada simpul graf sedemikian sehingga dua simpul bertetangga mempunyai warna yang berbeda. Ada 3 macam pewarnaan graf, yaitu pewarnaan simpul, pewarnaan sisi, dan pewarnaan wilayah.
Berikut akan dibahas pewarnaan simpul saja. Pewarnaan simpul adalah memberi warna pada simpul-simpul di dalam graf sedemikian sehingga setiap dua simpul bertetangga mempunyai warna yang berbeda. Di dalam persoalan pewarnaan graf, kita tidak hanya sekedar mewarnai simpulsimpul dengan warna berbeda dari warna simpul tetangganya saja, namum kita juga menginginkan jumlah macam warna yang digunakan sesedikit mungkin. Kita dapat memberikan sembarang warna pada simpul-simpul asalkan berbeda dengan simpul-simpul tetangganya.

\section{B. Algoritma Welch Powell}

Algoritma Welch Powell merupakan salah satu algoritma pewarnaan graf yang melakukan pewarnaan berdasarkan derajat tertinggi dari simpul-simpulnya atau disebut largest degree ordering (ldo). Algoritma ini dapat digunakan untuk mewarnai sebuah graf secara efisien. Akan tetapi algoritma ini tidak selalu memberikan jumlah minimum warna yang diperlukan untuk mewarnai. Walaupun demikian, algoritma ini praktis untuk digunakan dalam mewarnai simpul graf. Algoritma Welch Powell ini dinyatakan sebagai berikut :

1. Urutkan simpul-simpul dari graf $\mathrm{G}$ dalam derajat yang menurun (urutan seperti ini tidak mungkin tidak unik karena beberapa simpul mungkin berderajat sama).

2. Gunakan satu warna untuk mewarnai simpul pertama (yang mempunyai derajat tertinggi) dan simpul-simpul lain (dalam urutan yang berurut) yang tidak bertetangga dengan simpul pertama ini.

3. Mulai lagi dengan simpul derajat tertinggi berikutnya di dalam daftar terurut yang belum diwarnai dan ulangi proses pewarnaan simpul dengan menggunakan warna kedua.

4. Ulangi penambahan warna-warna sampai semua simpul telah diwarnai.

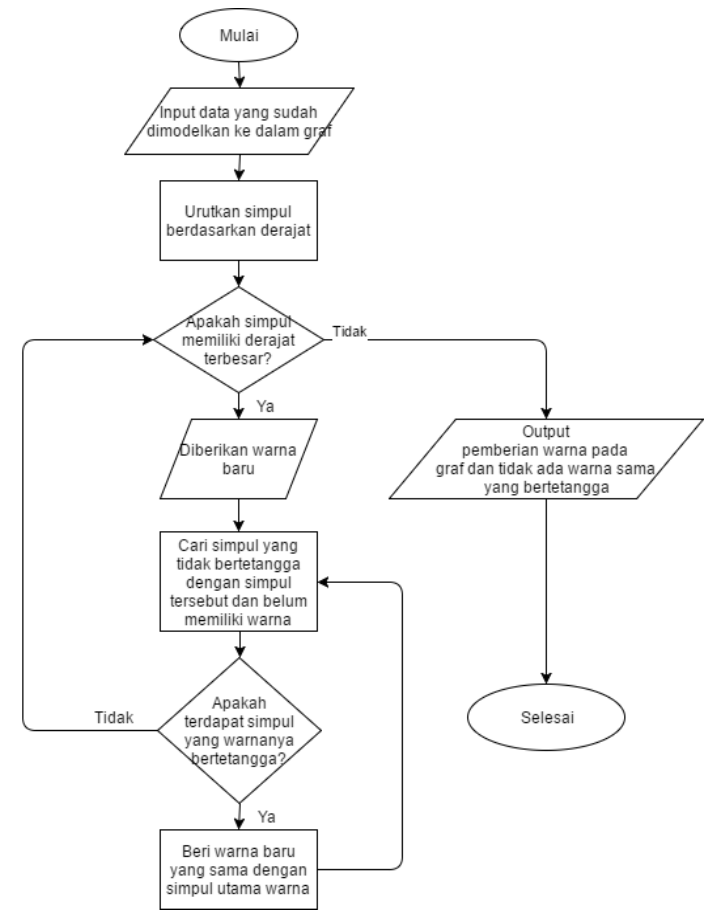

Gambar 1. Flowchart Algoritma Welch Powell. 


\section{Bilangan Kromatik}

Jumlah warna minimum yang dapat digunakan untuk mewarnai simpul yang ada pada graf $G$ disebut bilangan kromatik, disimbolkan dengan $\chi(G)$. Suatu graf $\mathrm{G}$ yang mempunyai bilangan kromatik $k$ dilambangkan dengan $\chi(G)=k$, sehingga graf berikut ini memiliki $\chi(G)=3$.

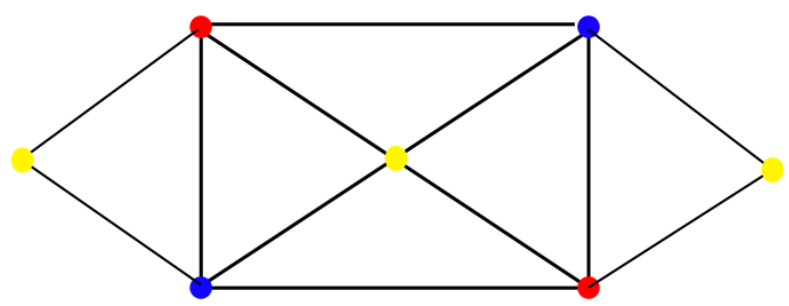

Gambar 2. Graf yang memiliki $\chi(G)=3$.

Beberapa graf tertentu dapat langsung ditentukan bilangan kromatiknya, yaitu :

a. Graf kosong $G=N_{n}$ memiliki $\chi(G)=1$, karena semua simpul tidak terhubung, jadi untuk mewarnai semua simpul cukup dibutuhkan satu warna saja.

b. Graf lengkap $G=K_{n}$ memiliki $\chi(G)=n$, karena smeua simpul saling terhubung sehingga diperlukan $n$ buah warna.

c. Graf bipartit $G=K_{m, n}$ memiliki $\chi(G)=2$, satu untuk simpul-simpul di himpunan $V_{1}$ dan satu lagi untuk simpulsimpul di $V_{2}$.

d. Graf lingkaran $G$ dengan $n$ ganjil memiliki $\chi(G)=3$, sedangkan jika $n$ genap maka $\chi(G)=2$.

e. Sembarang pohon T memiliki $\chi(T)=2$

f. Untuk graf-graf yang lain tidak dapat dinyatakan secara umum bilangan kromatiknya.

\section{Spektrum Frekuensi Radio}

Spektrum frekuensi radio adalah susunan pita frekuensi radio yang mempunyai frekuensi lebih kecil dari $3000 \mathrm{GHz}$ sebagai satuan getaran gelombang elektromagnetik yang merambat dan terdapat dalam dirgantara (ruang udara dan antariksa). Pengalokasian Spektrum Frekuensi Radio di Indonesia mengacu kepada alokasi frekuensi radio internasional untuk region 3. Region 3 (wilayah 3) sesuai dengan peraturan radio yang ditetapkan oleh International Telecommunication Union (ITU) atau Himpunan Telekomunisai Internasional. Penepatan jalur Spektrum frekuensi radio ini bertujuan untuk menghindari terjadinya interferensi (Interference) dan untuk menetapkan protokol demi keserasian antara pemancar dan penerima.

\section{E. Frekuensi Radio FM}

Frekuensi radio FM adalah proses mengirimkan sinyal Frekuensi rendah dengan menggunakan FM (Frequency Modulation). Metode modulasi frekuensi memvariasikan frekuensi untuk mengantarkan gelombang frekuensi radio. Frekuensi radio FM pertama kali ditemukan oleh Edwin Howard Amstrong pada tahun 1936, dimana frekuensi radio FM memiliki kelebihan tahan terhadap noise dibandingkan Frekuensi AM. Jarak tempuh frekuensi radio FM mencapai 60
Km dari pusat pemancar sinyal. Jarak tempuh frekuensi FM lebih kecil dibandingkan frekuensi AM. Frekuensi radio AM dapat mencapai jarak $100 \mathrm{Km}$ dari pusat pemancar sinyal, dikarenakan sinyal frekuensi radio AM dipantulkan oleh ionosfer [8]. Interval frekuensi radio FM adalah $15 \mathrm{~Hz}$ sampai $50 \mathrm{~Hz}$. Frekuensi radio FM dialokasiskan pada range frekuensi $88 \mathrm{MHz}$ sampai $108 \mathrm{MHz}$. Range frekuensi tersebut relatif baik terhadap gangguan atmosfir maupun cuaca.

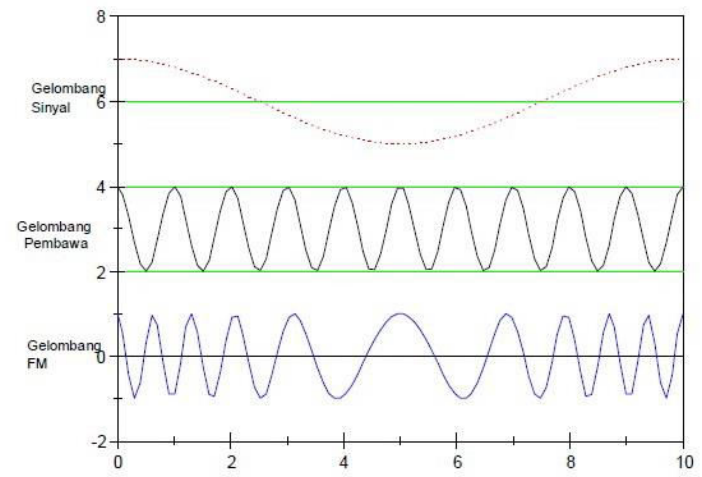

Gambar 3. Frekuensi Radio FM.

\section{HASIL DAN PEMBAHASAN}

Interferensi merupakan permasalahan yang menjadi tinjauan dalam penelitian ini. Interferensi disebabkan oleh radio yang memiliki frekuensi sama saling berdekatan, mengakibatkan dampak negatif yang signifikan terhadap kinerja jaringan nirkabel. Meminalisasi interferensi frekuensi radio adalah mengurangi terjadinya interferensi frekuensi radio pada frekuensi yang sama. Minimalisasi interferensi frekuensi radio bertujuan menghilangkan interferensi frekuensi radio pada radius yang bertubrukan, sehingga dapat mengurangi interferensi frekuensi radio di Jawa Timur. Algoritma Welch Powell yang digunakan dalam pewarnaan graf ternyata dapat diterapkan pada masalah interferensi penggunaan frekuensi radio. Misalkan pemancar dengan suatu frekuensi tertentu adalah suatu simpul. Pemancar yang memungkinkan akan berinterferensi dihubungkan dengan sisi, kita sebut kedua simpul yang dihubungkan sisi sebagai simpul yang bertetangga. Sesuai dengan algoritma Welch Powell, simpul yang bertetangga akan memiliki warna yang berbeda. Warna di sini adalah gambaran dari ferkuensi yang dimiliki suatu pemancar. Artinya, jika warna pemancar (simpul) adalah sama, maka pemancar tersebut seharusnya memiliki frekuensi radio yang sama. Jika pengaturan penggunaan frekuensi seperti ini digunakan, maka akan tercapai tujuan mengoptimalkan frekuensi radio, dengan mengakomodasikan pengguna frekuensi radio sebanyak-banyaknya dengan jumlah frekuensi yang digunakan sesedikit mungkin.

\section{A. Pengujian Program dengan Case Data Real}

Berikut ini akan dijelaskan pengujian perangkat lunak, user akan menguji beberapa poin permasalahan yang dapat diterapkan di dalam program. Hasil implementasi pengujian tersebut akan menjadi kajian dalam pengembangan dan pemeliharaan perangkat lunak. Program akan diuji dengan 4 
case. Dimana setiap case memiliki hasil inputan yang berbeda beda. Case 1 adalah setiap inputan posisi stasiun radio FM tidak mengalami interferensi. Case 2 adalah setiap inputan posisi stasiun radio FM mengalami interferensi. Case 3 adalah terdapat beberapa stasiun radio yang mengalami interferensi. Case 4 adalah case menggunakan data real posisi stasiun radio FM di Jawa Timur.

\section{B. Pengujian dengan Case Data Real}

Berdasarkan penjelasan pengujian dengan Kasus data real, maka posisi stasiun radio yang dipilih pemancar stasiun radio FM di Jawa Timur. Pada input posisi stasiun radio node berwarna hitam, diasumsikan bahwa pada tahap input setiap stasiun radio memiliki frekuensi yang sama. Sehingga hasil input ditunjukan pada Gambar 4.

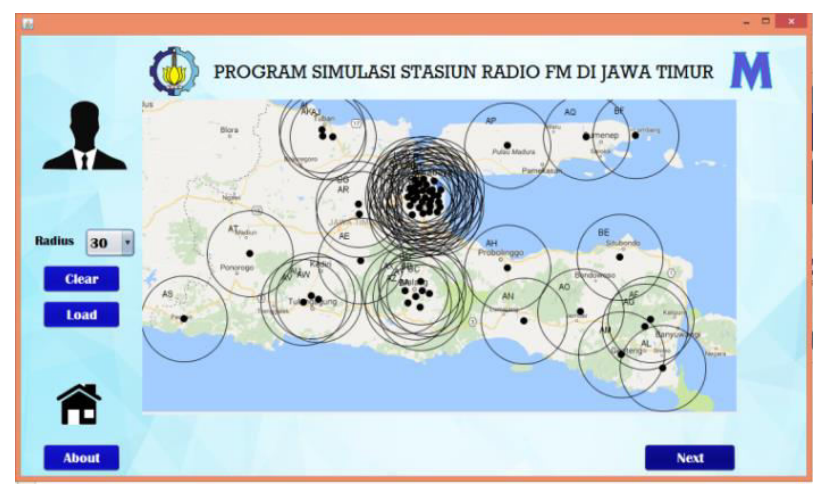

Gambar 4. Input Case Data Real.

Berdasarkan hasil input, selanjutnya input tersebut akan diperoleh dan diproses menjadi sebuah graf. Pemberian input posisi stasiun radio FM kasus data real menghasilkan beberapa node yang memiliki lintasan dengan node yang lain. Hal tersebut dikarenakan beberapa node mengalami interferensi. Dan hasil represesntasi graf dapat dilihat pada Gambar 5.

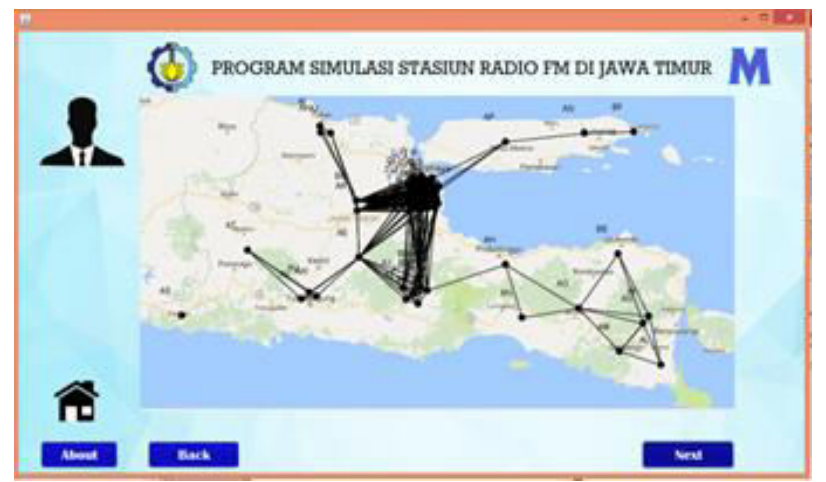

Gambar 5. Representasi Graf Case Data Real.

Berdasarkan hasil representasi graf, selanjutnya input tersebut akan diolah dan diproses menjadi hasil pewarnaan graf. Pemberian input posisi stasiun radio FM kasus data real menghasilkan terdapat node memiliki lintasan dengan node yang lain. Hal tersebut dikarenakan beberapa node mengalami interferensi. Maka hasil pewarnaan graf pada kasus data real memiliki n warna, hal tersebut menunjukan bahwa pada Kasus data real memiliki warna yang bervariasi. Dan hasil pewarnaan graf dapat dilihat pada Gambar 6 .

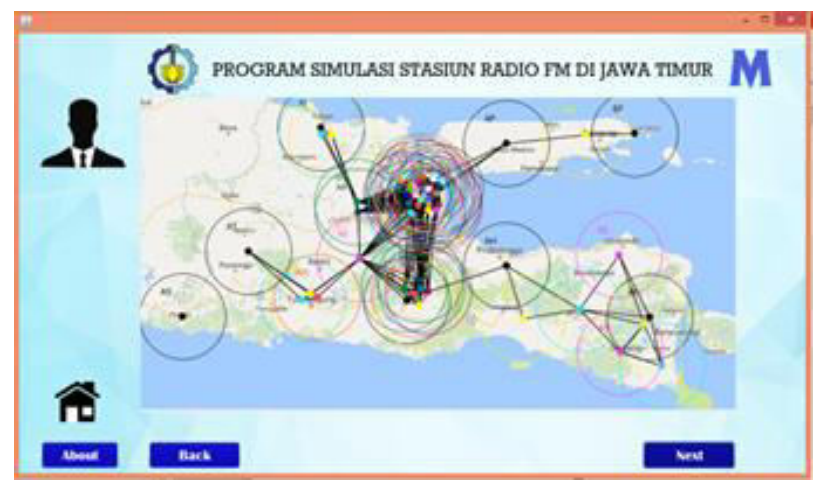

Gambar 6. Pewarnaan Graf Case Data Real.

Berdasarkan hasil pewarnaan graf, selanjutnya input tersebut akan diolah dan diproses menjadi hasil rekomendasi frekuensi radio FM. Pemberian input posisi stasiun radio FM kasus data real menghasilkan beberapa stasiun radio FM memiliki frekuensi yang berbeda-beda. Hal tersebut dikarenakan beberapa node mengalami interferensi dan beberapa node tidak mengalami interferensi. Maka hasil rekomendasi frekuensi pada kasus data real memiliki 33 frekuensi. Rekomendasi frekuensi dikatakan optimum karena dengan jumlah stasiun pemancar yang banyak hanya memerlukan beberapa alokasi frekuensi untuk dapat diterapkan. Hasil rekomendasi frekuensi menggunakan perangkat lunak menunjukan bahwa jumlah frekuensi yang digunakan sebanyak 33 frekuensi berbeda dan lebih optimum dibandingkan data real yang berjumlah 54 frekuensi berbeda. Hasil rekomendasi frekuensi dapat dilihat pada Gambar 7.

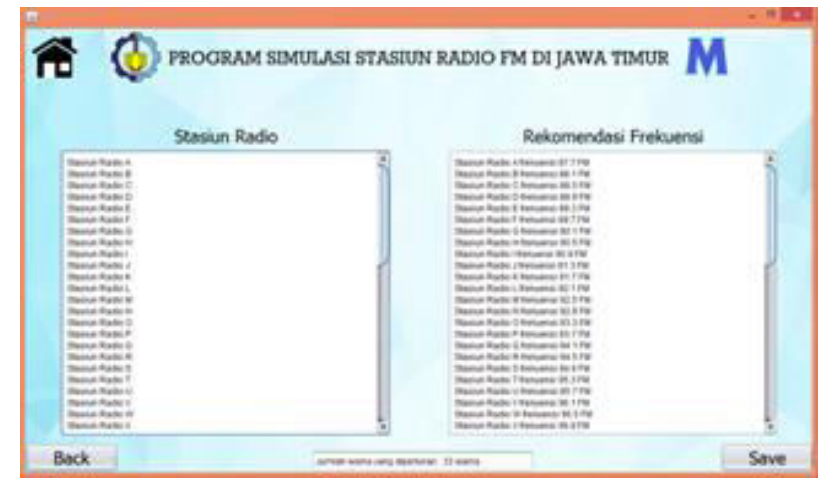

Gambar 7. Hasil Rekomendasi Frekuensi Case Data Real.

\section{KESIMPULAN/RINGKASAN}

Berdasarkan analisis terhadap hasil pengujian program, maka dapat diambil kesimpulan sebagai berikut :

1. Metode pewarnaan graf telah berhasil diterapkan untuk menghindari interferensi frekuensi radio FM di Jawa Timur.

2. Algoritma Welch Powell dapat mengoptimalkan pemakaian frekuensi radio FM yang relatif terhadap posisi 
dan coverage area stasiun radio FM tanpa adanya interferensi..

3. Untuk pengujian pada kasus 1 dimana semua pengguna tidak mengalami interferensi, Kasus 2 dimana semua pengguna mengalami, Kasus 3 dimana beberapa pengguna mengalami interferensi, menunjukan bahwa perangkat lunak dapat digunakan untuk mengakomodasi stasiun radio sebanyak-banyaknya, dengan jumlah frekuensi seminimal mungkin.

4. Untuk pengujian pada kasus data real dimana data yang digunakan adalah data asli tahun 2006 menunjukan bahwa perangkat lunak dapat menghasilkan pengalokasian frekuensi yang lebih optimal dibandingkan data frekuensi yang digunakan pada tahun 2006

\section{DAFTAR PUSTAKA}

[1] Ditjen Postel, "Master Plan Penetapan Frekuensi Kanal Radio Siaran Fm," Jakarta, 2016.

[2] A. . . Hassan and A. Chickade, "A Review Of Interference Reduction In Wireless Networks Using Graph Coloring Methods," Villanova, 2011.

[3] Z. Ning and Y. Yao, "Interference-Aware Spectrum Sensing Mechanismsin Cognitive Radio Networks," Shenyang. 